\title{
PENGARUH KUALITAS PELAYANAN BEA PEROLEHAN HAK ATAS TANAH DAN BANGUNAN (BPHTB) TERHADAP KEPUASAN WAJIB PAJAK PADA KANTOR BADAN PENGELOLAAN PENDAPATAN DAERAH (BAPPENDA) KABUPATEN BOGOR
}

\author{
${ }^{1)}$ Wawan Hari Subagyo, ${ }^{2)}$ Rina Melliza \\ ${ }^{1)}$ Dosen Program Studi Manajemen, STIE Dewantara \\ J1. Raya Pemda Bojong Depok Baru III, Karadenan, Cibinong, Bogor, Jawa Barat 16913, Indonesia \\ Email: wawan.hari@dewantara.ac.id \\ ${ }^{2)}$ Program Studi Manajemen, STIE Dewantara \\ J1. Raya Pemda Bojong Depok Baru III, Karadenan, Cibinong, Bogor, Jawa Barat 16913, Indonesia \\ Email: rvz.meliiza@gmail.com
}

\begin{abstract}
The tax on Land and Building Rights (BPHTB) is one of the sources of regional acceptance of Bogor District. This research aims to determine the influence of quality of service including simplicity, clarity, certainty, accuracy, security, responsibility, completeness of facilities and infrastructure, ease of access, discipline, politeness and friendliness, and Comfort to the taxpayer satisfaction at the office of BAPPENDA Bogor District. Samples used were 121 respondents. Data analysis techniques using multiple linear regression methods. The results of the analysis show Simplicity (X1), Certainty time (X3), Responsibility (X6) and Ease of Access $(X 8)$ does not affect the taxpayer satisfaction (Y). While the Variable Clarity (X2), Accuracy (X4), Security (X5), Completeness of Facilities and Infrastructure (X7), Discipline, Courtesy and Friendliness (X9) and Convenience (X10) affect the Satisfaction of Taxpayers (Y) at BAPPENDA Office of Bogor District.
\end{abstract}

Keywords: The tax on Land and Building Rights (BPHTB), BAPPENDA Bogor District, Multiple Linear Regression.

\begin{abstract}
ABSTRAK
Pajak Bea Perolehan Hak atas Tanah dan Bangunan (BPHTB) merupakan salah satu sumber penerimaan daerah kabupaten Bogor. Penelitian ini bertujuan untuk mengetahui pengaruh kualitas pelayanan meliputi kesederhanaan, kejelasan , kepastian, akurasi, keamanan, tanggung jawab, kelengkapan sarana dan prasarana, kemudahan akses, kedisiplinan, kesopanan dan keramahan, dan kenyamanan terhadap Kepuasan Wajib Pajak pada kantor BAPPENDA kabupaten Bogor. Sampel yang digunakan 121 responden. Teknik analisis data menggunakan metode Regresi Linier Berganda. Hasil analisis menunjukkan Kesederhanaan (X1), Kepastian Waktu (X3), Tanggung Jawab (X6) dan Kemudahan Akses (X8) tidak berpengaruh terhadap Kepuasan Wajib Pajak (Y). Sedangkan variable Kejelasan $\left(\mathrm{X}_{2}\right)$, Akurasi $\left(\mathrm{X}_{4}\right)$, Keamanan $\left(\mathrm{X}_{5}\right)$, Kelengkapan sarana dan prasarana $\left(\mathrm{X}_{7}\right)$, Kedisiplinan, Kesopanan dan Keramahan $\left(\mathrm{X}_{9}\right)$ dan Kenyamanan $\left(\mathrm{X}_{10}\right)$ berpengaruh terhadap Kepuasan Wajib Pajak $(\mathrm{Y})$ pada kantor BAPPENDA kabupaten Bogor.
\end{abstract}

Kata kunci: Bea Perolehan Hak atas Tanah dan Bangunan (BPHTB), BAPPENDA Kabupaten Bogor, Regresi Linier Berganda.

\begin{tabular}{ll}
\hline 1. PENDAHULUAN & dasar bagi daerah otonom untuk \\
Kebijakan otonomi daerah & melaksanakan pembangunan di daerahnya \\
memberikan hak, wewenang dan kewajiban & masing-masing berdasarkan potensi yang \\
daerah otonom untuk mengatur dan & dimiliki. Pembangunan di daerah \\
mengurus sendiri urusan pemerintahan dan & membutuhkan dana dalam jumlah yang \\
kepentingan masyarakat setempat sesuai & tidak sedikit. Pengelolaan yang baik dan \\
dengan peraturan perundang-undangan. & benar dalam penggalian dana sebagai \\
Kebijakan ini diharapkan dapat menjadi & sumber pembiayaan pelaksanaan
\end{tabular}


pembangunan tersebut dibutuhkan. Pengelollan dana pembangunan juga harus dilaksanakan sesuai dengan arah pembangunan tersebut diantaranya bersumber dari penerimaan pajak dan retribusi daerah.

Melihat kondisi di atas, pajak daerag memiliki peran penting dalam didalam instrument bahwa Bea Perolehan Hak atas Tanah dan Bangunan (BPHTB) merupakan salah satu sumber penerimaan daerah yang dihimpun dari masyarakat. Dana yang dihimpun tersebut kemudian digunakan sebagai sumber pembiayaan pembangunan yang dilakukan di daerah. Berbagai informasi tentang pajak ini tentu akan dengan sangat dibutuhkan oleh masyarakat.

Selama kurun waktu dijalankannya BPHTB sebagai pajak daerah ini, cukup memberikan kontribusi yang baik untuk pemerintahan daerah. Hal ini terbukti dari penerimaan total per tahunnya yang mengalami peningkatan. Adapun peningkatan data Penerimaan BPHTB dapat dilihat pada Tabel 1 . berikut.

Tabel 1. Realisasi Penerimaan BPHTB Kabupaten Bogor

\begin{tabular}{|c|c|c|}
\hline Tahun & Target (Rp.) & Penerimaan (Rp.) \\
\hline 2014 & 310.000 .000 .000 & 408.744 .070 .388 \\
\hline 2015 & 365.000 .000 .000 & 417.713 .890 .073 \\
\hline 2016 & 405.135 .579 .000 & 505.652 .631 .452 \\
\hline Sumber & Dinas Pendapatan Daerah
\end{tabular}

Kabupaten Bogor, 2016

Berdasarkan tabel di atas dapat dilihat bahwa BPHTB yang baru berjalan sebagai pajak daerah sudah terlihat memberikan hasil yang hampir setiap tahunnya memperoleh penerimaan yang melebihi target. Hal ini disebabkan oleh kesadaran masyarakat sebagai wajib pajak dalam membayar pajak. Dimana semakin tinggi tingkat kesadaran masyarakat dalam membayar pajak maka akan berpengaruh pada peningkatan penerimaan pajak. Salah satu faktor yang mempengaruhi kesadaran masyarakat dalam membayar pajak adalah tingkat kepercayaan terhadap efektivitas sistem pelayanan publik yang dikelola oleh negara. Pelayanan publik dapat dimaknai sebagai pemberian pelayanan (melayani) keperluan orang atau masyarakat yang mempunyai kepentingan pada organisasi sesuai dengan aturan pokok dan tata cara yang telah di tetapkan. (Widodo, 2001).

\subsection{Tujuan Penelitian}

Adapun Tujuan penelitian ini adalah:

1. Mengetahui pengaruh kualitas pelayanan BPHTB yang terdiri dari Kesederhanaan $\left(\mathrm{X}_{1}\right)$, Kejelasan $\left(\mathrm{X}_{2}\right)$, Kepastian Waktu $\left(\mathrm{X}_{3}\right)$, Akurasi $\left(\mathrm{X}_{4}\right)$, Keamanan $\left(\mathrm{X}_{5}\right)$, Tanggung Jawab $\left(\mathrm{X}_{6}\right)$, Kelengkapan Sarana dan Prasarana $\left(\mathrm{X}_{7}\right)$ Kemudahan Akses $\left(\mathrm{X}_{8}\right)$, Kedisiplinan, Kesopanan dan Keramahan $\left(\mathrm{X}_{9}\right)$ dan Kenyamanan $\left(\mathrm{X}_{10}\right)$ secara parsial terhadap kepuasan wajib pajak pada Kantor BAPPENDA Kabupaten Bogor.

2. Mengetahui pengaruh kualitas pelayanan BPHTB yang terdiri dari Kesederhanaan $\left(\mathrm{X}_{1}\right)$, Kejelasan $\left(\mathrm{X}_{2}\right)$, Kepastian Waktu $\left(\mathrm{X}_{3}\right)$, Akurasi $\left(\mathrm{X}_{4}\right)$, Keamanan $\left(\mathrm{X}_{5}\right)$, Tanggung Jawab $\left(\mathrm{X}_{6}\right)$, Kelengkapan Sarana dan Prasarana $\left(\mathrm{X}_{7}\right)$ Kemudahan Akses $\left(\mathrm{X}_{8}\right)$, Kedisiplinan, Kesopanan dan Keramahan $\left(\mathrm{X}_{9}\right)$ dan Kenyamanan $\left(\mathrm{X}_{10}\right)$ secara bersama-sama (simultan) terhadap kepuasan wajib pajak pada Kantor BAPPENDA Kabupaten Bogor.

3. Mengetahui besarnya pengaruh kualitas pelayanan BPHTB terhadap kepuasan wajib pajak pada Kantor BAPPENDA Kabupaten Bogor.

4. Mengetahui variabel yang dominan mempengaruhi kepuasan wajib pajak pada Kantor BAPPENDA Kabupaten Bogor. 


\section{TINJAUAN PUSTAKA}

Menurut Ratminto dan Winarsi (2005), Pelayanan adalah produk-produk yang tidak kasat mata (tidak dapat diraba) yang melibatkan usaha-usaha manusia dan menggunakan peralatan.

\subsection{Prinsip Pelayanan Publik}

Berdasarkan Keputusan Menteri Pendayagunaan Aparatur Negara Nomor 63/KEP/M.PAN/7/2003 Tentang Pedoman Umum Penyelenggaraan Pelayanan Publik dijelaskan Prinsip Pelayanan Publik yang harus dipedomani secara baik agar pelayanan publik dapat berjalan secara efektif dan tercapai tingkat kepuasan masyarakat yang optimal. Prinsip-prinsip pelayanan publik tersebut adalah sebagai berikut:

1. Kesederhanaan

Prosedur pelayanan publik tidak berbelit-belit, mudah dipahami dan mudah dilaksanakan.

2. Kejelasan
a. Persyaratan teknis dan administratif pelayanan publik;
b. Unit kerja/pejabat yang berwenang dan bertanggungjawab dalam memberikan pelayanan dan penyelesaian keluhan/ persoalan/sengketa/ dalam pelaksanaan pelayanan publik;
c. Rincian biaya pelayanan publik dan tata cara pembayaran.

3. Kepastian Waktu

Pelaksanaan pelayanan publik dapat diselesaikan dalam kurun waktu yang telah ditentukan.

4. Akurasi

Produk pelayanan diterima dengan benar, tepat dan sah.

5. Keamanan

Proses dan produk pelayanan publik memberikan rasa aman dan kepastian hukum.

6. Tanggung jawab

Pimpinan penyelenggara pelayanan publik atau pejabat yang ditunjuk bertanggungjawab atas

penyelenggaraan pelayanan dan penyelesaian keluhan/persoalan dalam pelaksanaan pelayanan publik.

7. Kelengkapan sarana dan prasarana

Tersedianya sarana dan prasarana kerja,

peralatan kerja dan pendukung lainnya yang memadai termasuk penyediaan sarana teknologi telekomunikasi dan informasi (telematika).

8. Kemudahan Akses

Tempat dan lokasi serta sarana pelayanan yang memadai, mudah dijangkau oleh masyarakat, dan dapat memanfaatkan teknologi telekomunikasi dan informatika.

9. Kedisiplinan, Kesopanan dan Keramahan

Pemberi pelayanan harus bersikap disiplin, sopan dan santun, ramah, serta memberikan pelayanan dan ikhlas.

10. Kenyamanan

Lingkungan pelayanan harus tertib, teratur, disediakan ruang tunggu yang nyaman, bersih dan rapi, lingkungan yang indah dan sehat serta dilengkapi dengan fasilitas pendukung pelayanan, seperti parkir, toilet, tempat ibadah dan lain-lain.

\subsection{Kepuasan Pelanggan}

Pengertian kepuasaan pelanggan menurut Oliver dalam Supranto (2001) menyatakan bahwa Kepuasan adalah tingkat perasaan seseorang setelah membandingkan kinerja produk atau hasil yang ia rasakan dengan harapannya. Menurut Kotler dalam Surjadi (2012:49), menyatakan bahwa kepuasan pelanggan adalah tingkat perasaan seseorang setelah membandingkan kinerja yang ia rasakan dengan harapan.

\subsection{Faktor-faktor Kepuasan Masyarakat}

Dalam pelayanan publik yang diselenggarakan oleh pemerintah, faktor- 
faktor kepuasan masyarakat sebagai penerima pelayanan dipengaruhi oleh standar-standar pelayanan ideal yang sesuai dengan prinsip pelayanan. Berdasarkan Keputusan Menteri Pendayagunaan Aparatur Negara Nomor Kep/25/M.Pan/2/2004 Tentang Pedoman Umum Penyusunan Indeks Kepuasan Masyarakat Unit Pelayanan Instansi Pemerintah, terdapat unsur minimal yang harus ada untuk dasar pengukuran indeks kepuasan masyarakat, yaitu :

1. Prosedur pelayanan, yaitu kemudahan tahapan pelayanan yang diberikan kepada masyarakat dilihat dari sisi kesederhanaan alur pelayanan;

2. Persyaratan Pelayanan, yaitu persyaratan teknis dan administrasi yang diperlukan untuk mendapatkan pelayanan sesuai dengan jenis pelayanannya;

3. Kejelasan petugas pelayanan, yaitu keberadaan dan kepastian petugas yang memberikan pelayanan (nama, jabatan serta kewenangan dan tanggung jawabnya);

4. Kedisplinan petugas pelayanan, yaitu kesungguhan petugas dalam memberikan pelayanan terutama terhadap konsistensi waktu kerja sesuai ketentuan yang berlaku;

5. Tanggung jawab petugas pelayanan, yaitu kejelasan wewenang dan tanggung jawab petugas dalam memberikan/menyelesaikan pelayanan kepada masyarakat;

6. Kemampuan petugas pelayanan, yaitu tingkat keahlian dan keterampilan yang dimiliki petugas dalam memberikan/menyelesaikan pelayanan kepada masyarakat;

7. Kecepatan pelayanan, yaitu target waktu pelayanan dapat diselesaikan dalam waktu yang telah di tentukan oleh unit penyelenggara pelayanan;

8. Keadilan mendapatkan pelayanan, yaitu pelaksanaan pelayanan dengan tidak membedakan golongan/status masyarakat yang dilayani;

9. Kesopanan dan keramahan petugas, yaitu sikap dan perilaku petugas dalam memberikan pelayanan kepada masyarakat secara sopan dan ramah serta saling menghargai dan menghormati;

10. Kewajaran biaya pelayanan, yaitu keterjangkauan masyarakat terhadap besarnya biaya yang ditetapkan oleh unit pelayanan;

11. Kepastian biaya pelayanan, yaitu kesesuaian antara biaya yang dibayarkan dengan biaya yang telah ditetapkan;

12. Kepastian jadwal pelayanan, yaitu pelaksanaan waktu pelayanan, sesuai dengan ketentuan yang telah ditetapkan;

13. Kenyamana lingkungan, yaitu kondisi sarana dan prasarana pelayanan yang bersih, rapi dan teratur sehingga dapat memberikan rasa nyaman kepada peneriman pelayanan;

14. Keamanan pelayanan, yaitu terjaminnya tingkat keamanan lingkungan unit penyelenggara pelayanan ataupun sarana yang digunakan, sehingga masyarakat merasa tenang untuk mendapatkan pelayanan terhadap resiko-resiko yang diakibatkan dari pelaksanaan pelayanan.

\subsection{Kerangka Pemikiran}

Menurut Sekaran dalam Sugiyono (2011) mengemukakan bahwa kerangka berpikir merupakan model konseptual tentang bagaimana teori berhubungan dengan berbagai faktor yang telah didefininsikan sebagai hal yang penting jadi dengan demikian maka kerangka berpikir adalah sebuah pemahaman yang paling mendasar dan menjadi pondasi bagi setiap pemikiran atau suatu bentuk proses dari keseluruhan dari penelitian yang akan dilakukan. 


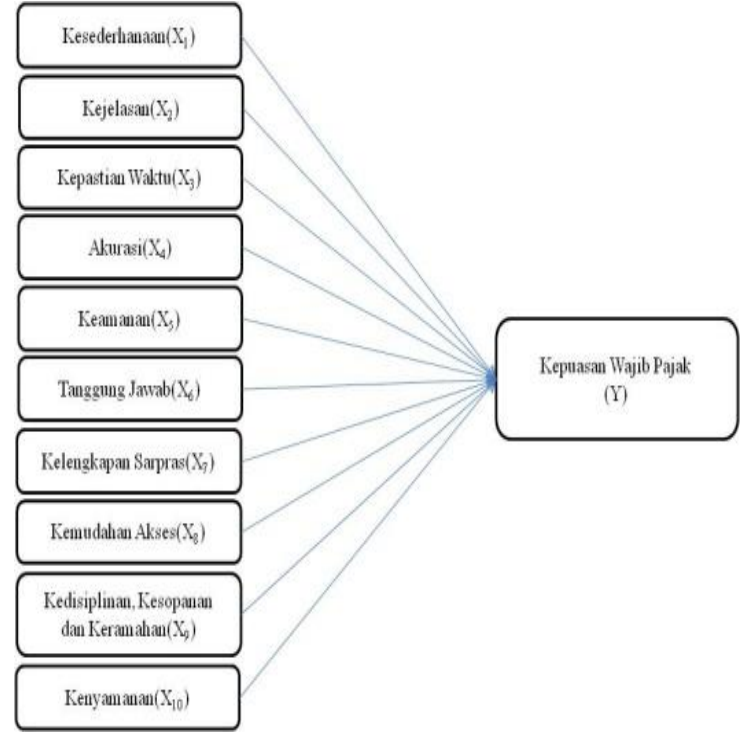

\section{Gambar 1. Kerangka Pemikiran Hipotesis Penelitian}

Berdasarkan konsep pemikiran diatas maka dalam penelitian ini hipotesis yang diajukan adalah sebagai berikut:

1. $\mathrm{H}_{0}$ : Tidak terdapat pengaruh kualitas pelayanan BPHTB yang terdiri dari Kesederhanaan $\left(\mathrm{X}_{1}\right)$, Kejelasan $\left(\mathrm{X}_{2}\right)$, Kepastian Waktu $\left(\mathrm{X}_{3}\right)$, Akurasi $\left(\mathrm{X}_{4}\right)$, Keamanan $\left(\mathrm{X}_{5}\right)$, Tanggung Jawab $\left(\mathrm{X}_{6}\right)$, Kelengkapan Sarana dan Prasarana $\left(\mathrm{X}_{7}\right)$, Kemudahan Akses $\left(\mathrm{X}_{8}\right)$, Kedisiplinan, Kesopanan dan Keramahan $\left(\mathrm{X}_{9}\right)$ dan Kenyamanan $\left(\mathrm{X}_{10}\right)$ secara parsial terhadap kepuasan wajib pajak Pada Kantor BAPPENDA Kabupaten Bogor.

$\mathrm{H}_{\mathrm{a}}$ : Terdapat pengaruh kualitas pelayanan BPHTB yang terdiri dari Kesederhanaan $\left(\mathrm{X}_{1}\right)$, Kejelasan $\left(\mathrm{X}_{2}\right), \quad$ Kepastian Waktu ( $\left.\mathrm{X}_{3}\right)$, Akurasi $\left(\mathrm{X}_{4}\right)$, Keamanan $\left(\mathrm{X}_{5}\right)$, Tanggung Jawab $\left(\mathrm{X}_{6}\right)$, Kelengkapan Sarana dan Prasarana $\left(\mathrm{X}_{7}\right)$, Kemudahan Akses $\left(\mathrm{X}_{8}\right), \quad$ Kedisiplinan, Kesopanan dan Keramahan $\left(\mathrm{X}_{9}\right)$ dan Kenyamanan $\left(\mathrm{X}_{10}\right)$ secara parsial terhadap kepuasan wajib pajak Pada Kantor BAPPENDA Kabupaten Bogor.

2. $\mathrm{H}_{0}$ : Tidak terdapat pengaruh kualitas pelayanan BPHTB yang terdiri dari Kesederhanaan $\left(\mathrm{X}_{1}\right)$, Kejelasan $\left(\mathrm{X}_{2}\right), \quad$ Kepastian Waktu ( $\left.\mathrm{X}_{3}\right)$, Akurasi $\left(\mathrm{X}_{4}\right)$, Keamanan $\left(\mathrm{X}_{5}\right)$, Tanggung Jawab $\left(\mathrm{X}_{6}\right)$, Kelengkapan Sarana dan Prasarana $\left(\mathrm{X}_{7}\right)$, Kemudahan Akses $\left(\mathrm{X}_{8}\right)$, Kedisiplinan, Kesopanan dan Keramahan $\left(\mathrm{X}_{9}\right)$ dan Kenyamanan $\left(\mathrm{X}_{10}\right)$ secara bersama-sama terhadap kepuasan wajib pajak Pada Kantor BAPPENDA Kabupaten Bogor.

$\mathrm{H}_{\mathrm{b}}$ : Terdapat pengaruh kualitas pelayanan BPHTB yang terdiri dari Kesederhanaan $\left(\mathrm{X}_{1}\right)$, Kejelasan $\left(\mathrm{X}_{2}\right), \quad$ Kepastian Waktu $\left(\mathrm{X}_{3}\right)$, Akurasi $\left(\mathrm{X}_{4}\right)$, Keamanan $\left(\mathrm{X}_{5}\right)$, Tanggung Jawab $\left(\mathrm{X}_{6}\right)$, Kelengkapan Sarana dan Prasarana $\left(\mathrm{X}_{7}\right)$, Kemudahan Akses $\quad\left(\mathrm{X}_{8}\right), \quad$ Kedisiplinan, Kesopanan dan Keramahan $\left(\mathrm{X}_{9}\right)$ dan Kenyamanan $\left(\mathrm{X}_{10}\right)$ secara bersama-sama terhadap kepuasan wajib pajak Pada Kantor BAPPENDA Kabupaten Bogor.

\section{METODE PENELITIAN}

\subsection{Populasi dan Sampel}

Populasi dalam penelitian ini adalah masyarakat/wajib pajak di Kabupaten Bogor. Menurut Roscoe (1982) bahwa ukuran sampel yang layak dalam penelitian kuantitatif adalah 30 sampai dengan 500 . Bila menggunakan analisis multivariate (korelasi dan regresi) maka sampelnya adalah $10 \mathrm{x}$ jumlah variabel.

\subsection{Variabel Penelitian}

Dalam penelitian ini jumlah variabel adalah 11 variabel (1 variabel terikat dan 
10 variabel bebas). Dengan demikian sampel yang diambil sebanyak 110. Teknik pengambilan sampel dengan menggunakan teknik incidental sampling adalah teknik penentuan sampel berdasarkan kebetulan, yaitu siapa saja yang secara kebetulan/insidental bertemu dengan peneliti dapat digunakan sebagai sampel, bila dipandang orang yang kebetulan ditemui itu cocok dengan sumber data (Sugiyono, 2012).

\subsection{Teknik Pengumpulan Data}

Pengumpulan data pada penelitian ini menggunakan kuesioner dengan skala Likert menggunakan 5 kategori pengukuran. Selain itu, menggunakan studi pustaka, yaitu pengumpulan data yang diperoleh dari dokumen dan literatur.

\subsection{Analisis Data}

\subsubsection{Metode Uji Kuesioner}

Didalam penelitian ini menggunakan metode uji kuesioner menggunakan uji validitas dan reliabilitas.

\subsubsection{Metode Uji Data Asusmsi Klasik}

Didalam penelitian ini metode uji data menggunakan uji normalitas, multikolinieritas dan heteroskedastisitas.

\subsubsection{Analisis Regresi Linier Berganda}

Teknik analisis data menggunakan regresi linier berganda, dengan persamaan regresi sebagai berikut :

$$
\begin{gathered}
Y=a+b_{1} X_{1}+b_{2} X_{2}+b_{3} X_{3}+b_{4} X_{4}+b_{5} X_{5}+ \\
b_{6} X_{6}+b_{7} X_{7}+b_{8} X_{8}+b_{9} X_{9}+b_{10} X_{10}
\end{gathered}
$$

Keterangan :

$\begin{array}{ll}\mathrm{Y} & : \text { Kepuasan Wajib Pajak' } \\ \mathrm{a} & : \text { Konstanta } \\ \mathrm{b} & : \text { Koefisien } \\ \mathrm{X}_{1} & : \text { Kesederhanaan } \\ \mathrm{X}_{2} & : \text { Kejelasan } \\ \mathrm{X}_{3} & : \text { Kepastian Waktu } \\ \mathrm{X}_{4} & : \text { Akurasi } \\ \mathrm{X}_{5} & : \text { Keamanan }\end{array}$

$\mathrm{X}_{6} \quad$ : Tanggung Jawab

$\mathrm{X}_{7}$ : Kelengkapan Sarana dan Prasarana

$\mathrm{X}_{8}$ : Kemudahan Akses

$\mathrm{X}_{9}$ : Kesopanan dan Keramahan

$\mathrm{X}_{10}$ : Kenyamanan

\subsubsection{Metode Uji Hipotesis}

Didalam penelitian ini metode uji hipotesis menggunakan menggunakan uji secara parsial (uji t) dan uji secara silmutan(uji F).

\section{HASIL DAN PEMBAHASAN}

Badan Pengelolaan Pendapatan Daerah Kabupaten Bogor (BAPPENDA) Berdasarkan Peraturan Bupati Bogor Nomor 70 Tahun 2016 merupakan unsur penunjang urusan pemerintahan yang melaksanakan fungsi penunjang keuangan di bidang pendapatan daerah. Visi BAPPENDA menjadi Badan Pengelolaan Pendapatan Daerah termaju di Indonesia.

\subsection{Metode Uji Kuesioner}

\subsubsection{Uji Validitas}

Uji validitas dilakukan membandingkan nilai $r_{\text {tabel }}$ dengan derajat bebas $\mathrm{df}=\mathrm{n}-\mathrm{k}-1=110-10-1=99$, pada tingkat kesalahan (error) 5\%. Maka diperoleh nilai $r_{\text {tabel }}$ sebesar 0,186. Hasil uji validitas menunjukkan bahwa semua indikator yang digunakan untuk mengukur variabel-variabel yang digunakan dalam penelitian ini mempunyai nilai koefisien korelasi ( $r_{\text {hitung }}$ ) yang lebih besar dari $r_{\text {tabel. }}$ Dengan demikian semua indikator pengukur variabel kualitas pelayanan 934 pertanyaan) dan kepuasan wajib pajak (14 pertanyaan) adalah valid.

\subsubsection{Uji Reliabilitas}

Uji Reliabilitas adalah uji yang dilakukan untuk mengukur data kehandalan yang menyangkut kekonsistenan jawaban responden jika diujikan berulang pada sampel yang berbeda. Hasil uji Cronbach Alpha $(\alpha)$ variabel kualitas pelayanan $(0,917)$ dan kepuasan wajib pajak $(0,909)$ 
menunjukkan hasil konsisten karena nilai Cronbach Alpha > 0,60.

\subsection{Metode Uji Data Asumsi Klasik}

\subsubsection{Uji Normalitas}

Uji normalitas atau homogenitas data menggunakan grafik P-Plot, menunjukkan data menyebar disekitar garis diagonal. Maka sebaran data memenuhi asumsi normalitas.

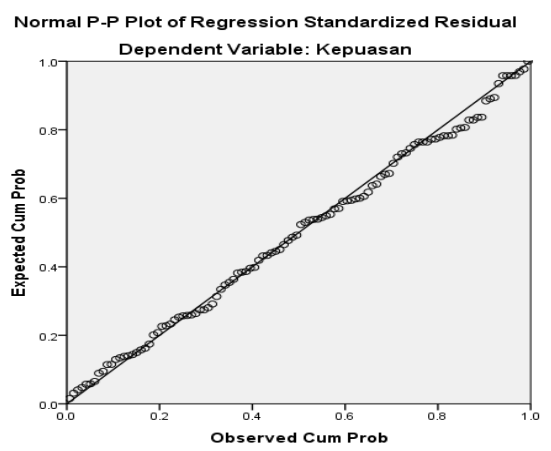

Gambar 2. Hasil Uji Normalitas Data

\subsubsection{Uji Heterokedastisitas}

Pengujian heterokedastisitas dilakukan menggunakan scatterplots. Berdasarkan hasil scatterplots diperoleh hasil titik- titik menyebar secara acak serta tersebar baik di atas maupun di bawah angka 0 dan sumbu Y. Hal ini dapat disimpulkan bahwa tidak terjadi heteroskedastisitas pada model regresi linier berganda.

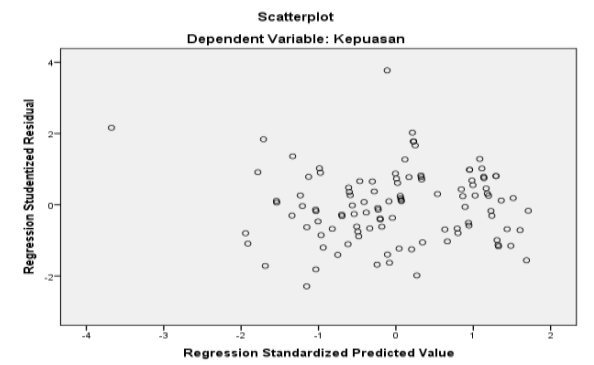

Gambar 3. Hasil Uji Heteroskedastisitas

\subsubsection{Uji Multikolinieritas}

Hasil uji multikolinieritas menunjukkan bahwa tidak semua variabel yang digunakan sebagai prediktor model regresi menunjukkan nilai VIF yang cukup kecil, di mana terdapat variabel yang nilai VIF menunjukkan nilai lebih besar dari 10 yaitu variabel Kejelasan (X2), Akurasi (X4), Keamanan (X5), Tanggung Jawab (X6), Kelengkapan Sarana dan Prasarana (X7), Kedisiplinan, Kesopanan dan Keramahan (X9). Sedangkan variabel yang nilai VIF di bawah 10 adalah variabel Kesederhanaan (X1), Kepastian Waktu (X3), Kemudahan Akses (X8), Kenyamanan (X10). Hal ini berarti bahwa variabel-variabel bebas yang nilainya kurang dari 10 tidak menunjukkan adanya gejala mulitikolinieritas. Sedangkan variabel yang nilai VIF lebih dari 10 , menunjukkan gejala multikolinieritas.

Berdasarkan hasil uji multikolinieritas di atas terdapat variabel dengan gejala multikolinieritas maka untuk mengatasi hal tersebut menurut Montgomery et al., 2006, dapat dilakukan dengan menambah jumlah sampel penelitian. Dalam penelitian ini jumlah sampel yang awalnya berjumlah 110 ditambah 11 sampel sehingga menjadi 121 sampel. Kemudian data diuji kembali. Berikut ini hasil uji multikolinieritas setelah sampel ditambahkan menjadi 121 sampel.

Tabel 2. Hasil Uji Multikolinieritas dengan Perubahan Jumlah Sampel

\begin{tabular}{|c|c|c|c|}
\hline \multicolumn{4}{|c|}{ Coefficients $^{\mathrm{a}}$} \\
\hline \multirow{2}{*}{\multicolumn{2}{|c|}{ Model }} & \multicolumn{2}{|c|}{ Collinearity Statistics } \\
\hline & & Tolerance & VIF \\
\hline \multirow[t]{11}{*}{1} & (Constant) & & \\
\hline & Kesederhaaan &, 337 & 2,964 \\
\hline & Kejelasan &, 250 & 3,999 \\
\hline & $\begin{array}{l}\text { Kepastian } \\
\text { Waktu }\end{array}$ &, 221 & 4,527 \\
\hline & Akurasi &, 215 & 4,652 \\
\hline & Keamanan &, 252 & 3,962 \\
\hline & $\begin{array}{l}\text { Tanggung } \\
\text { Jawab }\end{array}$ &, 157 & 6,359 \\
\hline & Sarpras &, 162 & 6,185 \\
\hline & Akses &, 184 & 5,430 \\
\hline & Kedisiplinan & ,203 & 4,923 \\
\hline & Kenyamanan & ,260 & 3,840 \\
\hline
\end{tabular}

a. Dependent Variable: Y 
Hasil pengujian dari tabel di atas menunjukkan bahwa semua variabel yang di gunakan sebagai prediktor model regresi menunjukkan nilai VIF yang lebih kecil dari 10, dan nilai tolerance di atas 0,1 . Dengan demikian dapat disimpulkan bahwa dalam penelitian ini tidak terjadi multikolinieritas.

\subsection{Analisis Regresi Linier Berganda}

Hasil uji analisis regresi linier berganda pengaruh variabel bebas erhadap variabel terikat dapat dilihat pada tabel berikut.

Tabel 3. Hasil Uji Analisis Regresi Linier Berganda

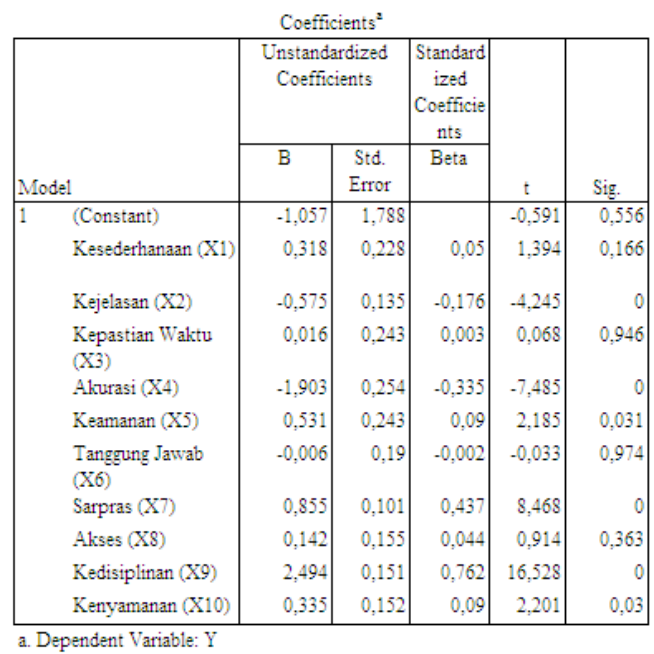

Berdasarkan hasil uji regresi linier berganda diperoleh persamaan regresi yaitu: $\mathrm{Y}=-1.057+0,318 \mathrm{X}_{1}-0,575 \mathrm{X}_{2}+$ $0,016 X_{3}-1,903 X_{4}+0,531 X_{5}-0,006 X_{6}+$ $0,855 X_{7}+0,142 X_{8}+2,494 X_{9}+0,335 X_{10}$.

\subsection{Metode Uji Hipotesis}

\subsubsection{Uji Hipotesis Secara Parsial (Uji t)}

Uji hipotesis pengaruh variabel bebas terhadap variabel terikat dilakukan dengan uji t. Nilai $t_{\text {tabel }}$ pada derajad bebas $\mathrm{df}=\mathrm{n}-\mathrm{k}-$ $1=121-10-1=110$ dan nilai derajad kesalahan (error) 5\%, diperoleh nilai 0,1982. Berdasarkan tabel di atas dapat diketahui bahwa hasil uji hipotesis secara parsial membuktikan bahwa:
1. Hasil uji $t$ menunjukkan nilai $\mathrm{t}_{\text {hitung }}$ dari variabel Kesederhanaan $\left(\mathrm{X}_{1}\right)$, Kepastian Waktu $\left(\mathrm{X}_{3}\right)$, Tanggung Jawab $\left(\mathrm{X}_{6}\right)$ dan Kemudahan Akses $\left(\mathrm{X}_{8}\right)$ lebih kecil $(<)$ dari nilai $t_{\text {tabel }}$ $(1,982)$. Selain itu, nilai P-Value (sig) variable Kesederhanaan $\left(\mathrm{X}_{1}\right)$, Kepastian Waktu $\left(\mathrm{X}_{3}\right)$, Tanggung Jawab $\left(\mathrm{X}_{6}\right)$ dan Kemudahan Akses $\left(\mathrm{X}_{8}\right)$ menunjukkan nilai lebih besar dari 0,05. Kesimpulan terima $\mathrm{H}_{0}$. Dengan demikian variabel Kesederhanaan $\left(\mathrm{X}_{1}\right)$, Kepastian Waktu $\left(\mathrm{X}_{3}\right)$, Tanggung Jawab $\left(\mathrm{X}_{6}\right)$ dan Kemudahan Akses $\left(\mathrm{X}_{8}\right)$ tidak berpengaruh terhadap Kepuasan Wajib Pajak (Y).

2. Hasil uji $\mathrm{t}$ menunjukkan nilai $\mathrm{t}_{\text {hitung }}$ dari variabel Kejelasan $\left(\mathrm{X}_{2}\right)$, Akurasi $\left(\mathrm{X}_{4}\right)$, Keamanan $\left(\mathrm{X}_{5}\right)$, Kelengkapan sarana dan prasarana $\left(\mathrm{X}_{7}\right)$, Kedisiplinan, Kesopanan dan Keramahan $\left(\mathrm{X}_{9}\right)$ dan Kenyamanan $\left(\mathrm{X}_{10}\right)$ nilainya lebih besar (>) dari nilai $t_{\text {tabel }}(1,982)$. Selain itu, nilai P-Value (sig) variable Kejelasan $\left(\mathrm{X}_{2}\right)$, Akurasi $\left(\mathrm{X}_{4}\right)$, Keamanan $\left(\mathrm{X}_{5}\right)$, Kelengkapan sarana dan prasarana $\left(\mathrm{X}_{7}\right)$, Kedisiplinan, Kesopanan dan Keramahan $\left(\mathrm{X}_{9}\right)$ dan Kenyamanan $\left(\mathrm{X}_{10}\right)$ menunjukkan nilai lebih kecil dari 0,05. Kesimpulan Tolak $\mathrm{H}_{0}$. Dengan demikian, Variabel Kejelasan $\left(\mathrm{X}_{2}\right)$, Akurasi $\left(\mathrm{X}_{4}\right)$, Keamanan $\left(\mathrm{X}_{5}\right)$, Kelengkapan sarana dan prasarana $\left(\mathrm{X}_{7}\right)$, Kedisiplinan, Kesopanan dan Keramahan $\left(\mathrm{X}_{9}\right)$ dan Kenyamanan $\left(\mathrm{X}_{10}\right)$ berpengaruh terhadap Kepuasan Wajib Pajak (Y).

3. Variabel yang paling dominan mempengaruhi Kepuasan Wajib Pajak adalah variabel Kedisiplinan, Kesopanan dan Keramahan ( $\left.\mathrm{X}_{9}\right)$ dengan nilai koefisien persamaan regresi terbesar yaitu 2,494. 


\subsubsection{Uji Hipotesis Secara Simultan ( Uji} F)

Pengujian hipotesis pengaruh variabel bebas secara bersama-sama terhadap variabel terikatnya dilakukan dengan menggunakan uji $F$. Nilai $F_{\text {tabel }}$ dengan derajat bebas df $1=k=10$ dan df2 $=n-k-$ $1=121-10-1=110$ untuk sampel 121 diperoleh nilai sebesar 1,965 .

\section{Tabel 4. Hasil Uji Hipotesis Secara} Simultan (Uji F)

\begin{tabular}{|c|r|r|r|r|r|}
\hline Model & $\begin{array}{r}\text { Sum of } \\
\text { Squares }\end{array}$ & Df & $\begin{array}{l}\text { Mean } \\
\text { Square }\end{array}$ & F & Sig. \\
\hline Regression & 4433,409 & 10 & 443,341 & 220 & $.000^{\circ}$ \\
878 & & \\
1 Residual & 220,79 & 110 & 2,007 & & \\
Total & 4654,198 & 120 & & & \\
a. Dependent Variable: Y \\
b. Predictors: (Constant), X1, X2, X3, X4, X5, X6, X7, X8, X9, X10
\end{tabular}
T

Berdasarkan hasil perhitungan stastistik menunjukan $F_{\text {hitung }}=220,878$ lebih besar dari nilai $\mathrm{F}_{\text {tabel }}(1,965)$. Sedangkan nilai $\mathrm{P}$-value (sig) sebesar 0,000 kurang dari $(<)$ 0,05. Kesimpulan tolak $\mathrm{H}_{0}$. Dengan demikian, variabel $\left(\mathrm{X}_{1}\right)$ Kesederhanaan, Kejelasan $\left(\mathrm{X}_{2}\right)$, Kepastian Waktu $\left(\mathrm{X}_{3}\right)$, Akurasi $\left(\mathrm{X}_{4}\right)$, Keamanan $\left(\mathrm{X}_{5}\right)$, Tanggung Jawab $\left(\mathrm{X}_{6}\right)$, Kelengkapan Sarana dan Prasarana $\left(\mathrm{X}_{7}\right)$, Kemudahan Akses $\left(\mathrm{X}_{8}\right)$, Kesopanan dan Keramahan $\left(\mathrm{X}_{9}\right)$, Kenyamanan $\left(\mathrm{X}_{10}\right)$ secara silmutan berpengaruh terhadap Kepuasan Wajib Pajak (Y).

\subsection{Uji Koefisien Determinasi}

Koefisien determinasi digunakan untuk mengetahui seberapa besar pengaruh variabel-variabel bebas memiliki pengaruh terhadap variabel terikatnya. Hasil uji koefisien determinasi sebagai berikut:
Tabel 5. Hasil Uji Koefisien Determinasi Model Summary ${ }^{\mathrm{b}}$

\begin{tabular}{|l|c|r|r|r|}
\hline Model & $\mathrm{R}$ & $\begin{array}{c}\mathrm{R} \\
\text { Square }\end{array}$ & $\begin{array}{c}\text { Adjusted } \\
\mathrm{R} \\
\text { Square }\end{array}$ & $\begin{array}{c}\text { Std. } \\
\text { Error of } \\
\text { the } \\
\text { Estimate }\end{array}$ \\
\hline 1 & $.976^{\mathrm{a}}$ &, 953 &, 948 & 1,41675 \\
\hline
\end{tabular}

a. Predictors: (Constant), X1, X2, X3, X4, X5,

X6, X7, X8, X9, X10

b. Dependent Variable: $Y$

Nilai koefisien determinasi ditentukan dengan nilai adjusted $R$ square. Hasil uji koefisien determinasi menunjukkan bahwa koefisien determinasi (adjusted $\mathrm{R}^{2}$ ) yang diperoleh sebesar 0,948. Hal ini menunjukan bahwa 94,8\% Kepuasan Wajib Pajak (Y) dipengaruhi oleh Kesederhanaan $\left(\mathrm{X}_{1}\right)$, Kejelasan $\left(\mathrm{X}_{2}\right)$,

Kepastian Waktu $\left(\mathrm{X}_{3}\right)$, Akurasi $\left(\mathrm{X}_{4}\right)$, Keamanan $\left(\mathrm{X}_{5}\right)$, Tanggung Jawab $\left(\mathrm{X}_{6}\right)$, Kelengkapan Sarana dan Prasarana $\left(\mathrm{X}_{7}\right)$, Kemudahan Akses $\left(\mathrm{X}_{8}\right)$, Kedisiplinan, Kesopanan dan Keramahan $\left(\mathrm{X}_{9}\right)$, dan Kenyamanan $\left(\mathrm{X}_{10}\right)$. Sedangkan sisanya $5,2 \%$ dipengaruhi oleh faktor lain yang tidakditeliti dalam penelitian ini.

\section{KESIMPULAN DAN SARAN}

\subsection{Kesimpulan}

Berdasarkan hasil penelitian yang telah diuraikan, maka kesimpulan dalam penelitian ini adalah:

1. Hasil uji hipotesis secara parsial membuktikan variable Kesederhanaan $\left(\mathrm{X}_{1}\right)$, Kepastian Waktu $\left(\mathrm{X}_{3}\right)$, Tanggung Jawab $\left(\mathrm{X}_{6}\right)$ dan Kemudahan Akses $\left(\mathrm{X}_{8}\right)$ terbukti tidak berpengaruh terhadap Kepuasan Wajib Pajak (Y). Sedangkan variable Kejelasan $\left(\mathrm{X}_{2}\right)$, Akurasi $\left(\mathrm{X}_{4}\right), \quad$ Keamanan $\left(\mathrm{X}_{5}\right)$, Kelengkapan sarana dan prasarana $\left(\mathrm{X}_{7}\right)$, Kedisiplinan, Kesopanan dan Keramahan $\left(\mathrm{X}_{9}\right)$ dan Kenyamanan $\left(\mathrm{X}_{10}\right)$ berpengaruh terhadap Kepuasan Wajib Pajak (Y). Untuk meningkatkan kepuasan wajib pajak, BAPPENDA perlu melakukan inovasi- 
inovasi pada proses dan prosedur pelayanan yang diberikan agar prosedur pelayanannya lebih sederhana, serta memberikan kepastian waktu dan kemudahan akses bagi wajib pajak.

2. Hasil uji hipotesis secara simultan membuktikan variabel kualitas pelayanan publik yang meliputi Kesederhanaan $\left(\mathrm{X}_{1}\right)$, Kejelasan $\left(\mathrm{X}_{2}\right)$, Kepastian Waktu $\left(\mathrm{X}_{3}\right)$, Akurasi $\left(\mathrm{X}_{4}\right)$, Keamanan $\left(\mathrm{X}_{5}\right)$, Tanggung Jawab $\left(\mathrm{X}_{6}\right)$, Kelengkapan Sarana dan Prasarana $\left(\mathrm{X}_{7}\right)$ Kemudahan Akses $\left(\mathrm{X}_{8}\right)$, Kedisiplinan, Kesopanan dan Keramahan $\left(\mathrm{X}_{9}\right)$, dan Kenyamanan $\left(\mathrm{X}_{10}\right)$ mempunyai pengaruh signifikan terhadap Kepuasan Wajib Pajak (Y). Hal ini ditunjukkan dari nilai p-value $(0,00)$ di bawah 0,05 .

3. Hasil uji koefisien determinasi dapat diketahui bahwa koefisien determinasi (adjusted $\mathrm{R}^{2}$ ) yang diperoleh sebesar 0,948 . Hal ini menunjukan bahwa 94,8\% Kepuasan Wajib Pajak (Y) dipengaruhi oleh pelayanan publik meliputi Kesederhanaan $\left(\mathrm{X}_{1}\right)$, Kejelasan $\left(\mathrm{X}_{2}\right)$, Kepastian Waktu $\left(\mathrm{X}_{3}\right)$, Akurasi $\left(\mathrm{X}_{4}\right), \quad$ Keamanan $\left(\mathrm{X}_{5}\right)$, Tanggung Jawab $\left(\mathrm{X}_{6}\right)$, Kelengkapan Sarana dan Prasarana $\left(\mathrm{X}_{7}\right)$, Kemudahan Akses $\left(\mathrm{X}_{8}\right)$, Kedisiplinan, Kesopanan dan Keramahan $\left(\mathrm{X}_{9}\right)$, dan Kenyamanan $\left(\mathrm{X}_{10}\right)$. Sedangkan sisanya $5,2 \%$ dipengaruhi oleh faktor lain yang tidak diteliti pada penelitian ini.

4. Variabel yang paling dominan mempengaruhi kepuasan wajib pajak adalah variabel Kedisiplinan, Kesopanan dan Keramahan ( $\left.\mathrm{X}_{9}\right)$ dengan nilai koefisien regresi sebesar 2,494 .

\subsection{Saran}

Berdasarkan hasil penelitian secara keseluruhan dan simpulan yang diperoleh, saran bagi pihak-pihak yang berkepentingan dalam penelitian ini sebagai berikut :

1. Meningkatkan frekuensi penyuluhan dan sosialisasi kepada masyarakat tentang kewajiban membayar pajak BPHTB berikut prosedur dan tata caranya;

2. Memberikan pelayanan pajak BPHTB dengan tepat dan benar sesuai SOP terkait

3. Meningkatkan keamanan data pajak BPHTB dengan selalu berpedoman pada aspek hukum;

4. Memelihara sarana dan prasarana berupa (ruang tunggu berpendingin, kursi, TV, kamar mandi, form-form isian pajak, meja helpdesk, dll.) yang sudah ada di kantor Badan Pengelolaan Pendapatan Daerah (BAPPENDA) Kabupaten Bogor agar selalu dapat dimanfaatkan secara maksimal oleh para wajib pajak;

5. Meningkatkan kinerja para petugas pelayanan BPHTB, antara lain kecepatan pelayanan, keramahan dan respon cepat terhadap keluhan wajib pajak;

6. Selalu menjaga kenyamanan dan kebersihan lingkungan kantor Badan Pengelolaan Pendapatan Daerah (BAPPENDA) Kabupaten Bogor.

\section{DAFTAR PUSTAKA}

Augusty, F. 2006. Metode Penelitian Manajemen. Badan Penerbit Universitas Diponegoro. Semarang.

Dahmiri dan Suzana. 2013. Pengaruh Kualitas Pelayanan Terhadap Kepuasan Masyarakat Pada Dinas Kependudukan Dan Pencatatan Sipil Kabupaten Sarolangun (Studi Pada Mahasiswa Universitas Jambi). Skripsi. Prodi Manajemen Pemerintahan Universitas Jambi.

Fahmi, R., Rochmah, S., dan Siswidiyanto. 2012. Analisis Pengaruh Kualitas 
Pelayanan Publik Terhadap Kepuasan Masyarakat (Studi tentang Pelayanan Perekaman Kartu Tanda Penduduk Elektronik (e-KTP) di Kota Depok). Jurusan Administrasi Publik, Fakultas Ilmu Administrasi, Universitas Brawijaya, Malang.

Ghozali, I. 2005. Aplikasi Multivariate dengan Program SPSS. Badan Penerbit Universitas Diponegoro. Semarang.

Hadi, S. 2004. Metode Penelitian. PT. Gunung Agung. Jakarta.

Joko, S. 2012. 6 Hari Jago SPSS. Jakarta. Kotler, P. 2002. Manajemen Pemasaran. PT Prenhalilindo. Jakarta.

. 2005. Manajemen Pemasaran: Analisis perencanaan, Implementasi dan pengendalian (Edisi Kedua). Erlangga. Jakarta.

2005. Prinsip-prinsip Pemasaran Jilid I. Erlangga. Jakarta.

Kotler dan Amstrong. 2008. Prinsip-prinsip Pemasaran. Jilid 1 dan 2.Edisi 12. Erlangga. Jakarta.

Kotler dan Keller. 2009. Manajemen Pemasaran. Jilid I. Edisi ke 13. Jakarta: Erlangga.

Lupiyadi, R. 2006. Manajemen Pemasaran Jasa dan Praktek. PT.Salemba Empat. Jakarta.

Nur, I. dan Supomo, B. 2002. Metode Penelitian Bisnis. Cetakan kedua. BPFE Yogyakarta.

Parasuraman A, Zeithaml ZA dan Berr LL. 2008. Reassessment of Implication For Further Research. Journal of Marketing.

Pratama, AWE. 2014. Pengaruh Kualitas Pelayanan Terhadap Kepuasan Masyarakat (Studi Kasus Pada Kantor Kelurahan Sondakan Kecamatan Laweyan Kota Surakarta). Skripsi. Program Studi Manajemen Fakultas Ekonomi Dan Bisnis Universitas Muhammadiyah Surakarta.
Ratminto dan Septi, WA. 2005. Manajemen Pelayanan. Penerbit Pustaka Pelajar. Yogyakarta.

Susanto. 2009. Manajemen Personalia. Gunung Agung. Bandung.

Sugiarto, E. 2002. Psikologi Pelayanan dalam Industri Jasa. PT Gramedia Pustaka Utama, Jakarta.

Sugiyono. 2007. Statistika Untuk Penelitian. CV. Alfabeta. Bandung.

Singarimbun, M. dan Effendi, S. 2008. Metode Penelitian Survei. LPE. Jakarta.

Sumarman, U. 2003. Perilaku Konsumen. Ghalia Indonesia. Jakarta.

Tjiptono, F. 2005. Total Quality Service. Penerbit Andi. Jogjakarta

Tjiptono, F. 2006. Manajemen Jasa. Andi Offset. Yogyakarta.

Umar, H. 2002. Metode Penelitian Aplikasi dan Pemasaran. PT. Gramedia Pustaka Utama. Jakarta.

Yudianto. 2009. Pengaruh Kualitas Pelayanan Terhadap Tingkat Kepuasan Wajib Pajak Pada Kantor Pelayanan Pajak Pada Kantor Pelayanan Pajak Pratama Samarinda. Skripsi. Universitas Mulawarman. 